\title{
My Life as a Spy: Investigations in a Police File (2018)
}

Author: Katherine Verdery

London: Duke University Press

Language: English

My Life as a Spy: Investigations in a Secret Police File is the latest monograph by American anthropologist Katherine Verdery. While it sits among a growing literature of exploratory memoirs by victims of state surveillance, such as Garton-Ash's The File, My Life as a Spy attempts something intellectually distinct which she broadly frames as 'autoethnography' (p.28). My Life as a Spy is both an explicitly personal examination of her surveillance by the state and a work of cultural anthropology that conceptualises the Securitate as the product of, and process of, a social system.

Verdery spent much of the 70s and 80s conducting fieldwork in the Socialist Republic of Romania under the watchful eye of the Securitate, Romania's secret police. After the regime collapsed the extent of Securitate's monitoring of its citizens, and the scale of its informer network, came to light when the government (partially) opened the Securitate archives. My Life as A Spy reviews 11 volumes of files detailing Verdery's activities in Romania and America.

The first two-thirds of the book are primarily narrative, drawing extensively on her anthropological field notes, diaries, letters, and Securitate documents. These provide insight into her complex emotional responses to experiences and personal relationships with individuals that were or became Securitate informants, both before and after she learned of their informing. The final third details Securitate procedures, interviews with her informers, and an exploration of how to conceptualise the experiences of betrayal within a social system.

The 'autoethnography' methodology is complicated by the temporal and experiential layers involved. Her interpretations are drawn from ethnographic observation combined with close interrogation of the aforementioned documentation, through which she reconstructs her past in a kind of discordant dialogue between her own narrative and that of the Securitate. The sources are by their nature highly subjective: all attempt to capture the particulars of a situation but are from a single, interpretative standpoint. Most 'contributors' - both informers and officers - are given or presume a specific brief which focuses their gaze on certain behaviours or attributes.

By doing this, Verdery exposes the constructed and fragmented nature of her identity, both as a surveillance subject and as an anthropologist within a context of unfamiliar social 
networks. The refractions caused by deconstruction and reconstruction of meanings and identities are manifold. She, the observer, is also the observed, both by the local community in which she is embedded and by the secret agents who collate and interpret details of her life in order to prove her an enemy of the state. The later act of reading and interpreting her own file adds a further distortion, in which accounts by Securitate agents challenge confidence in past relations and conduct, former friendships and associations must be conceptually abandoned and re-approached, and the entirety of her fieldwork is called into question by the falsehood of the relational dynamics created by the secret police. The past becomes part panopticon, part hall of mirrors.

The autoethnographical approach has limitations. Few subjects of state observation have the academic discipline or emotional readiness to distance themselves from their experience as Verdery attempts. However, as modern societies increasingly live and present their lives on digital platforms, perhaps the increasingly fragmented and distorted representation of individuals will increase the need for this method of academic deconstruction and analysis. The overlap between her as subject and observer is also potentially problematic. Verdery frequently corrects information contained in her file, asserting where some event or detail is incorrectly reported. But how reliable is her version of events? What of bias, conscious or not? Should the subject be given ultimate control over 'truth'?

Trust and identity are at the heart of the book, as they are at the heart of anthropology. The realities of conducting ethnographic research in a police state are laid bare; it challenges one's assumptions about reliable identities and calls into question the very foundations of ethnographic research. This compelling book provides an extraordinary exploration of Securitate scrutiny as both a highly personal experiential account, and as an anthropologist's examination of that experience. It draws on the anthropologist's analytical toolkit to conceptualise and deconstruct those personal responses, and the result is an unusual and important contribution to our understanding of the socially-negotiated world of state surveillance.

\section{MEGAN PALMER \\ University College London}

This work is licensed under the Creative Commons Attribution-NonCommercial-ShareAlike 3.0 Unported License. To view a copy of this license, visit http://creativecommons.org/licenses/bync-sa/3.0/ or send a letter to Creative Commons, PO Box 1866, Mountain View, CA 94042, USA. 